\title{
Sintering behavior and thermal expansion of zirconia-titanium composites
}

\author{
Paula Lada $^{1} \cdot$ Aleksandra Miazga $^{1} \cdot$ Katarzyna Konopka $^{1} \cdot$ Mikołaj Szafran $^{2}$
}

Received: 14 July 2017/ Accepted: 31 October 2017/Published online: 11 November 2017

(c) The Author(s) 2017. This article is an open access publication

\begin{abstract}
The dilatometric and thermogravimetric methods were used to investigate the sintering conditions of $3 \mathrm{Y}-\mathrm{ZrO}_{2}$ and $3 \mathrm{Y}-\mathrm{ZrO}_{2}-\mathrm{Ti}$ composites. For the materials preparation, the nanometric zirconia stabilized by $3 \mathrm{~mol} \%$ $\mathrm{Y}_{2} \mathrm{O}_{3}$ powder and micrometric titanium powder ( 3 and $10 \mathrm{vol} \%$ ) were used. The green body samples were formed by slip casting method. The morphology of samples microstructures was determined by SEM observations. The stereological analysis of zirconia and zirconia-titanium composites was carried out using computer program. The density was measured using the Archimedes method. The hardness of sinters was also investigated. Addition of $\mathrm{Ti}$ into $\mathrm{ZrO}_{2}$ influenced the sintering behavior and thermal expansion of obtained composites. The analysis of the sintering process and characteristic temperatures confirmed the increase of onset and final temperature of shrinkage with the increase in $\mathrm{Ti}$ content. The changes of the thermal expansion curves for the pure zirconia and $3 \mathrm{Y}_{-} \mathrm{ZrO}_{2}-\mathrm{Ti}$ composites were the result of the $\alpha \mathrm{Ti} \rightarrow \beta \mathrm{Ti}$ transformation and the transition temperature of the zirconia $\mathrm{m} \rightarrow \mathrm{t}$ transformation. The zirconia and composite samples were characterized by relative density about $98 \%$, close to theoretical density. The slight growth of zirconia grains was observed.
\end{abstract}

Paula Łada

paula.lada@inmat.pw.edu.pl

1 Faculty of Materials Science and Engineering, Warsaw University of Technology, 141 Woloska St., 02-507 Warsaw, Poland

2 Faculty of Chemistry, Warsaw University of Technology, 3 Noakowskiego St., 00-664 Warsaw, Poland
Keywords Zirconia · Titanium · Composites · Dilatometry $\cdot$ Thermal expansion $\cdot$ Stereology

\section{Introduction}

Due to the properties, such as high strength, chemical stability, high thermal shock resistance, advanced biocompatibility, and high fracture toughness, yttria-stabilized zirconia is very popular ceramic material with the wide range of application in science and technology [1-3]. They are used as oxygen sensors, thermal barrier coatings, or medical implants and prosthesis [4-6].

Production of the composites with zirconia matrix is the response to the research for new materials with better, innovative properties. One of the solutions is the addition of metal particles into zirconia [7, 8]. Titanium is characterized by high chemical resistance, biocompatibility, high fatigue resistance, low thermal and electrical conductivity, no magnetic properties, and also high melting point $\left(1667{ }^{\circ} \mathrm{C}\right)[9,10]$. Due to these properties, it is a good component for the zirconia-based composites, especially for the biomedical applications. Additionally, the addition of Ti to zirconia ceramic materials decreases hardness and stiffness of composite material but it also increases fixation of the implant in the bone [11-13].

Determination of sintering temperature for the $3 \mathrm{Y}-$ $\mathrm{ZrO}_{2}-\mathrm{Ti}$ composites is one of the important steps to obtain the material characterized by high relative density. Furthermore, reaction between components may vary depending on the temperature. The study of reaction between zirconia and titanium was subject of the many researches. The first studies of the $\mathrm{ZrO}_{2}-\mathrm{Ti}$ system were carried out for the stabilization of zirconia by various kinds of dopants and the reaction of liquid titanium and its alloys 
due to the problem with ceramic molds for casting [14, 15]. The observations of the reaction between titanium and $\mathrm{ZrO}_{2}$ led to further studies at temperatures below the melting point of titanium [16, 17]. In results, Lin et al. [16] indicated the influence of the heating temperature of the reaction at the interface between zirconia and titanium. The temperature influences on the microstructure, composites phase composition, and the grain growth of zirconia. Moreover, the new phases from $\mathrm{Zr}-\mathrm{Ti}-\mathrm{O}$ system were identified [18].

Pure zirconia ceramics exhibit a phase transformation between monoclinic $\left(\mathrm{m}-\mathrm{ZrO}_{2}\right)$ to tetragonal $\left(\mathrm{t}-\mathrm{ZrO}_{2}\right)$ phases. The temperature of the $\mathrm{m} \rightarrow \mathrm{t}$ transformation during the heating is close to $1400{ }^{\circ} \mathrm{C}$. The zirconia stabilization by the $3 \mathrm{~mol} \% \quad \mathrm{Y}_{2} \mathrm{O}_{3}$ eliminated the reverse $\mathrm{t} \rightarrow \mathrm{m}$ transformation during the cooling. However, the titanium addition could affect the changes of $\mathrm{m} \rightarrow \mathrm{t}$ transformation temperatures and the amount of monoclinic phase in the sintered material $[3,19,20]$.

In the literature, data are many papers about the thermal behavior of yttria-stabilized zirconia ceramic [21-23]. The zirconia composites with $\mathrm{Ti}$ particle are still the new materials, which require the investigation of the thermal behavior during the sintering process. The aim of this work was the preparation of $3 \mathrm{Y}-\mathrm{ZrO}_{2}-\mathrm{Ti}$ composites with different content of titanium particles. The forming method was slip casting. The thermal expansion and physical properties were the subject of the investigation. The result will allow designing composites of $3 \mathrm{Y}-\mathrm{ZrO}_{2}-\mathrm{Ti}$ system. Conducting this type of research will allow to consciously designing materials from $3 \mathrm{Y}-\mathrm{ZrO}_{2}-\mathrm{Ti}$ system.

\section{Materials and experimental procedure}

The starting materials were commercial zirconia powder stabilized by $3 \mathrm{~mol} \% \mathrm{Y}_{2} \mathrm{O}_{3}$ (Tosoh, Japan) and pure titanium powder (Alfa Aesar, USA). Powders were characterized by the density of 5.92 and $4.45 \mathrm{~g} \mathrm{~cm}^{-3}$, respectively. The densities of powders were determined by a helium pycnometer AccuPyc 1340 II. The average particle diameters were measured by using SEM and were lower than $100 \mathrm{~nm}\left(3 \mathrm{Y}-\mathrm{ZrO}_{2}\right)$ and about $8-11 \mu \mathrm{m}(\mathrm{Ti})$, respectively.

The green bodies were formed by the slip casting method. The slip casting slurry was consisted of zirconia and titanium powders with the distillate water as a solvent (55 vol\%) and diammonium hydrocitrate as a deflocculant (0.3 mass\%-with respect to the mass of solid phase). The preparation of the slip casting slurries based on own earlier research. The detailed description of the procedure and characterization of slip casting slurries were presented in the paper [24]. Titanium powder content in the composite samples was 3 and 10 vol\%, respectively. Moreover, for comparative purposes, the pure zirconia samples were prepared.

The thermal analysis has been done for $3 \mathrm{Y}-\mathrm{ZrO}_{2}-\mathrm{Ti}$ green body samples. Differential thermal analysis (DTA) and thermogravimetric (TG) curves were obtained by using Netzsch STA 449C coupled with Quadrupole Mass Spectrometer Netzsch QMS 403C. The final temperature was $1450{ }^{\circ} \mathrm{C}$, and the heating rate was $10^{\circ} \mathrm{C} \mathrm{min}^{-1}$ in the constant flow of two gases: argon $10 \mathrm{~mL} \mathrm{~min}{ }^{-1}$ (protective gas) and argon $60 \mathrm{~mL} \mathrm{~min}{ }^{-1}$ (measurement gas). Mass spectrometer was set to detect $\mathrm{m} / \mathrm{z}$ values in mass range 10-300.

The cylindrical green bodies $(h=10 \mathrm{~mm}, d=8 \mathrm{~mm})$ prepared by slip casting method were tested in a differential dilatometer (Netzsch Dil 402E with the graphite furnace). The characteristic sintering temperatures were observed during the heating with heating rate of $10{ }^{\circ} \mathrm{C} \mathrm{min}{ }^{-1}$ in helium atmosphere. The temperature measurement range was $40-1450{ }^{\circ} \mathrm{C}$.

Selected physical properties were measured by Archimedes method. The hardness of the samples was determined by using Vickers hardness tester HVS-30T, Huatec Group Corporation.

The morphology of samples cross section was studied by SEM Hitachi SU-70. For observation, the samples were coated with a thin layer of carbon. The grain growth measurement was conducted for samples after thermal etching at $1350{ }^{\circ} \mathrm{C}\left(100{ }^{\circ} \mathrm{C}\right.$ lower than sintering temperature), during the $30 \mathrm{~min}$. Thermal etching allowed to determine zirconia grain size. The samples were also coated with a thin layer of carbon for observation after thermal etching. The first step was SEM observations of the zirconia matrix microstructure. The next step was stereological analysis on the image from SEM, which was conducted by using computer program MicroMeter [25]. The zirconia grains were described by the equivalent diameter $\left(d_{2}\right)$ (diameter of a circle having the same area as the surface of grain).

The sintered cylindrical samples were tested to obtain the thermal expansion curves from test with heating rate of $10{ }^{\circ} \mathrm{C} \mathrm{min}{ }^{-1}$. The temperature measurement range was $40-1450{ }^{\circ} \mathrm{C}$ by using a differential dilatometer in helium atmosphere.

All research was conducted with the using of inert gas atmosphere (helium and argon). For the preparation of zirconia-titanium composite, very necessary is the kind of sintering atmosphere. Titanium is characterized by high affinity for oxygen, nitrogen, and hydrogen. For the limited the reaction of these elements with $\mathrm{Ti}$ particle during the sintering process, the inert atmosphere should be used. 


\section{Results and discussion}

\section{Reaction sintering process}

Figure 1 shows the temperature plots characterized by variation in mass (TG curve) and thermal flow (DTA curve) during heating of selected samples- $3 \mathrm{Y}-\mathrm{ZrO}_{2}$ 10 vol\% Ti. The samples were prepared by slip casting method with the addition of deflocculant in the water solution. Heating of the powder up to $1450{ }^{\circ} \mathrm{C}$ is followed by increase in its mass by $0.45 \%$. The small mass loss was observed for temperature range of $400-600{ }^{\circ} \mathrm{C}$, which corresponded with the degradation of the slip casting additives. The results of mass spectrum measurement showed the existence of the peaks with $m / z=18,28$, and 44 in the mass spectrum taken within this temperature range, which were attributed to the molecules $\mathrm{H}_{2} \mathrm{O}, \mathrm{CO}$, and $\mathrm{CO}_{2}$, respectively, released from the powder sample. Removal of the slip casting additives did not result in peaks on the DTA curves. The DTA curve showed one exothermic effect at $838.6{ }^{\circ} \mathrm{C}$. These thermal changes were associated with a titanium oxidation and $\alpha \mathrm{Ti} \rightarrow \beta \mathrm{Ti}$ phase transformation. The $\alpha \mathrm{Ti} \rightarrow \beta \mathrm{Ti}$ transformation temperature for $\mathrm{Ti}$ is $882.5^{\circ} \mathrm{C}$ [26].

Figure 2 shows the variation in the shrinkage rate of zirconia and $3 \mathrm{Y}-\mathrm{ZrO}_{2}-\mathrm{Ti}$ samples as a function of heating temperature. The characteristic temperatures of the samples sintering are included in Table 1. The maximum densification rate for the samples under study falls at the $\mathrm{m} \rightarrow \mathrm{t}$ transformation temperature about $1300{ }^{\circ} \mathrm{C}$ and increases together with the increase of Ti content. The most valuable information is the onset temperature of macroscopic shrinkage. That is, the minimum temperature corresponding to starting of sudden decrease in the sample length due to the beginning of bulk sintering. The onset temperature of sintering increases with an increase of titanium content. The titanium content also had the influence on the shrinkage value of the samples. The lowest values of the shrinkage were observed for the pure zirconia sample. The addition of titanium gives the increase of the shrinkage. Figure 2 presented also the plot for $\mathrm{d} L / \mathrm{d} t$ versus temperature which corresponds with the microscopic sintering, where the shrinkage taking place within an agglomerate of powders.

\section{Materials characterization}

Table 2 shows the selected physical properties of zirconia and zirconia-titanium composites. Although the green densities of sample series were significantly differed, the relative density of the sinters was similar and close to theoretical densities for pure zirconia ceramic and $3 \mathrm{Y}-$ $\mathrm{ZrO}_{2}-\mathrm{Ti}$ composites. The addition of titanium did not influence on density of final material. Furthermore, the 3Y$\mathrm{ZrO}_{2}-3 \mathrm{vol} \%$ Ti composite was characterized by similar hardness to pure zirconia, but the addition of $10 \mathrm{vol} \% \mathrm{Ti}$ slightly decreased the composite hardness. The open porosity was low and similar for all samples.

The cross sections of samples were presented in Fig. 3 (a-c-for pure zirconia and zirconia-titanium composites, respectively). Slip casting method allowed forming composites with the homogeneous distribution of Ti-rich particles. The microstructures of pure zirconia and zirconia matrix of the composite samples after thermal etching were presented in Fig. 3a1, b1, c1.

The addition of titanium did not affect the zirconia particles' size distribution in the samples (Fig. 4). The mean grain size slightly increased with the increase of $\mathrm{Ti}$ content (Table 3). This can be related to the process of forming a new phase between $\mathrm{Ti}-\mathrm{ZrO}_{2}$ and therefore formation of zirconia with reduced oxygen content. Such

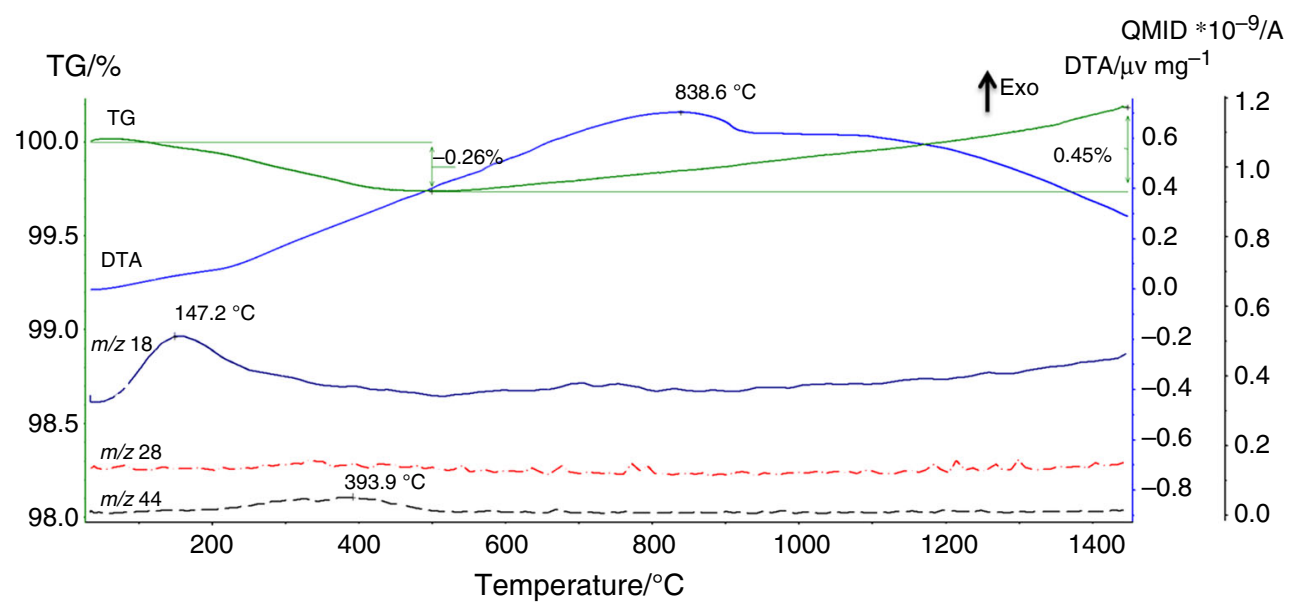

Fig. $1 \mathrm{TG} / \mathrm{DTA}$ curves of $3 \mathrm{Y}-\mathrm{ZrO}_{2}+10$ vol\% $\mathrm{Ti}$ composite powder with the slip casting additions 

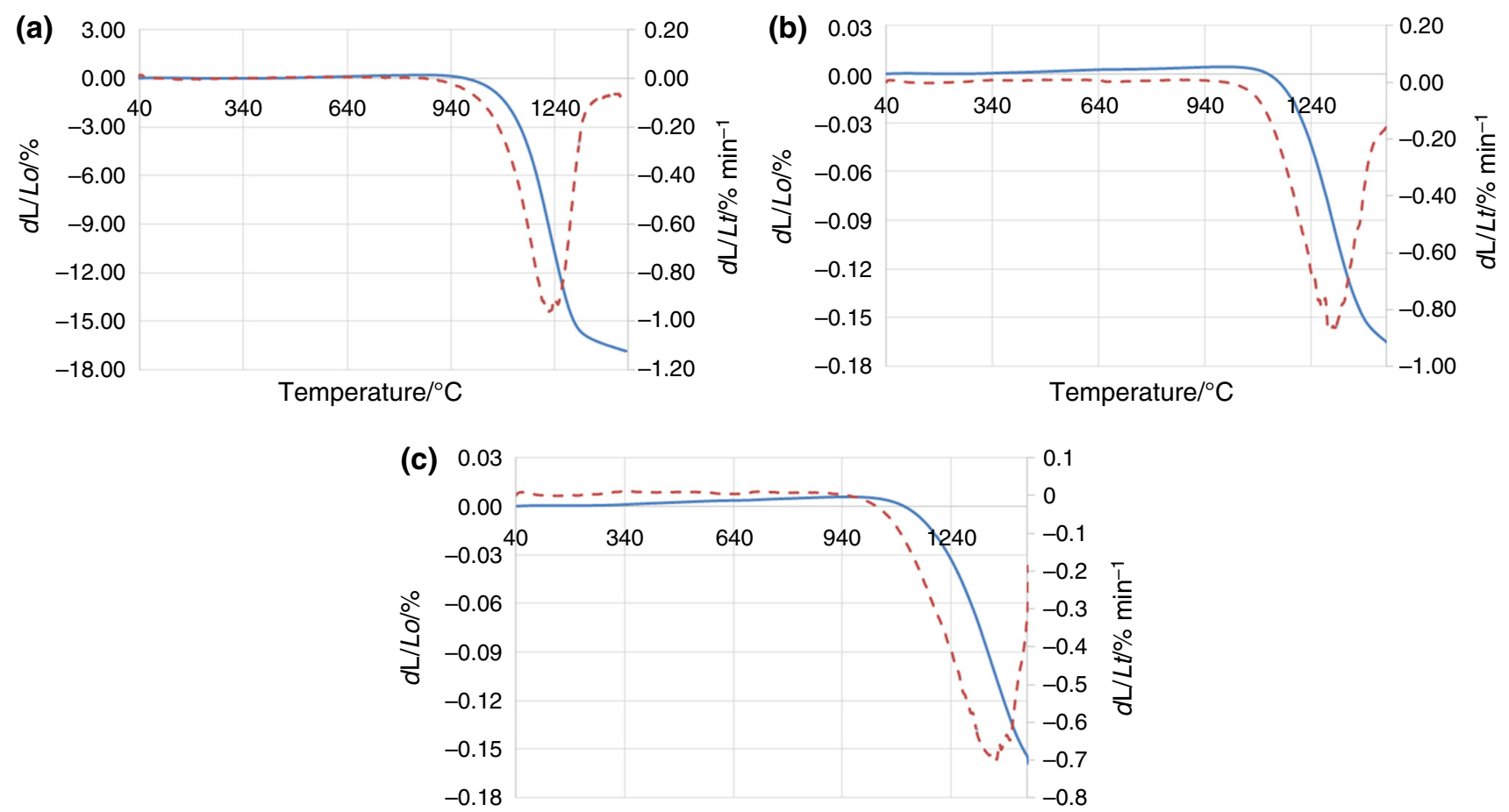

Temperature $/{ }^{\circ} \mathrm{C}$

Fig. 2 Shrinkage versus temperature recording during the heating part of cycle (solid line- $\mathrm{d} L / L o$ ) and derivative versus temperature of the curves (dotted line- $\mathrm{d} L / \mathrm{d} t$ ) for ceramic $3 \mathrm{Y}-\mathrm{ZrO}_{2}$ (a) and composites samples $3 \mathrm{Y}_{-} \mathrm{ZrO}_{2}-3$ vol\% $\mathrm{Ti}(\mathbf{b})$ and $3 \mathrm{Y}-\mathrm{ZrO}{ }_{2}-10 \mathrm{vol} \% \mathrm{Ti}(\mathbf{c})$

Table 1 Characteristic sintering temperatures and shrinkage during the heating

\begin{tabular}{llllll}
\hline & Sample & $\begin{array}{l}\text { Onset temperature } \\
\text { of sintering } /{ }^{\circ} \mathrm{C}\end{array}$ & $\begin{array}{l}\text { Finish temperature } \\
\text { of shrinkage } /{ }^{\circ} \mathrm{C}\end{array}$ & $\begin{array}{l}\text { Temperature of maximum } \\
\text { shrinkage rate } /{ }^{\circ} \mathrm{C}\end{array}$ & $\begin{array}{l}\text { Linear shrinkage/\% } \\
\text { A }\end{array}$ \\
\hline $\mathrm{Y}-\mathrm{ZrO}_{2}$ & 1127 & 1290 & 1290 & 16.64 \\
$\mathrm{C}$ & $3 \mathrm{Y}-\mathrm{ZrO}_{2}+3 \mathrm{vol} \% \mathrm{Ti}$ & 1184 & 1378 & 1291 & 17.71 \\
\hline
\end{tabular}

Table 2 Selected physical properties and hardness of the $3 \mathrm{Y}-\mathrm{ZrO}_{2}$ and $3 \mathrm{Y}-\mathrm{ZrO}_{2}-\mathrm{Ti}$ composites

\begin{tabular}{llllll}
\hline & & Green density/\% & Relative density/\% & Open porosity/\% & HV10/GPa \\
\hline A & $\mathrm{ZrO}_{2}$ & $53.14 \pm 1.98$ & $98.74 \pm 1.30$ & $0.21 \pm 0.12$ & $11.87 \pm 0.36$ \\
B & $\mathrm{ZrO}_{2}+3$ vol\% Ti & $61.24 \pm 2.01$ & $98.59 \pm 1.61$ & $0.46 \pm 0.09$ & $12.11 \pm 0.24$ \\
$\mathrm{C}$ & $\mathrm{ZrO}_{2}+10 \mathrm{vol} \% \mathrm{Ti}$ & $56.81 \pm 1.81$ & $98.56 \pm 1.56$ & $0.29 \pm 0.08$ & $10.92 \pm 0.36$ \\
\hline
\end{tabular}

changes of new phases from $\mathrm{Ti}-\mathrm{Zr}-\mathrm{O}$ system were observed in the literature earlier [16-18].

The thermal expansion and shrinkage curves of the studied materials are plotted in Fig. 5. The linear dimension for all samples, pure zirconia and $3 \mathrm{Y}-\mathrm{ZrO}_{2}-\mathrm{Ti}$ composites, was increased during the heating. However, the character of changes was different. The shrinkage for pure zirconia was linear up to $1300{ }^{\circ} \mathrm{C}$. For the composite samples the curves of shrinkage were diffrent. The 3Y$\mathrm{ZrO}_{2}-3$ vol. $\%$ Ti composite sample was characterized by shrinkage close to linear curve at temperatures range of $50-1200{ }^{\circ} \mathrm{C}$ and significant increase above $1200{ }^{\circ} \mathrm{C}$. The shrinkage curve of $3 \mathrm{Y}-\mathrm{ZrO}_{2}-10$ vol.\% Ti increased in non linear way.

Pure zirconia and $3 \mathrm{Y}-\mathrm{ZrO}_{2}-3$ vol\% Ti samples were characterized by similar thermal expansion curve at temperature range of $50-1200{ }^{\circ} \mathrm{C}$ with $\alpha \sim 11 \times 10^{-6} \mathrm{~K}^{-1}$. The small difference was observed for the temperature of $550{ }^{\circ} \mathrm{C}\left(\alpha \sim 8.2 \times 10^{-6} \mathrm{~K}^{-1}\right)$ which could correlate with the beginning of the titanium oxide changes [26, 27]. At 

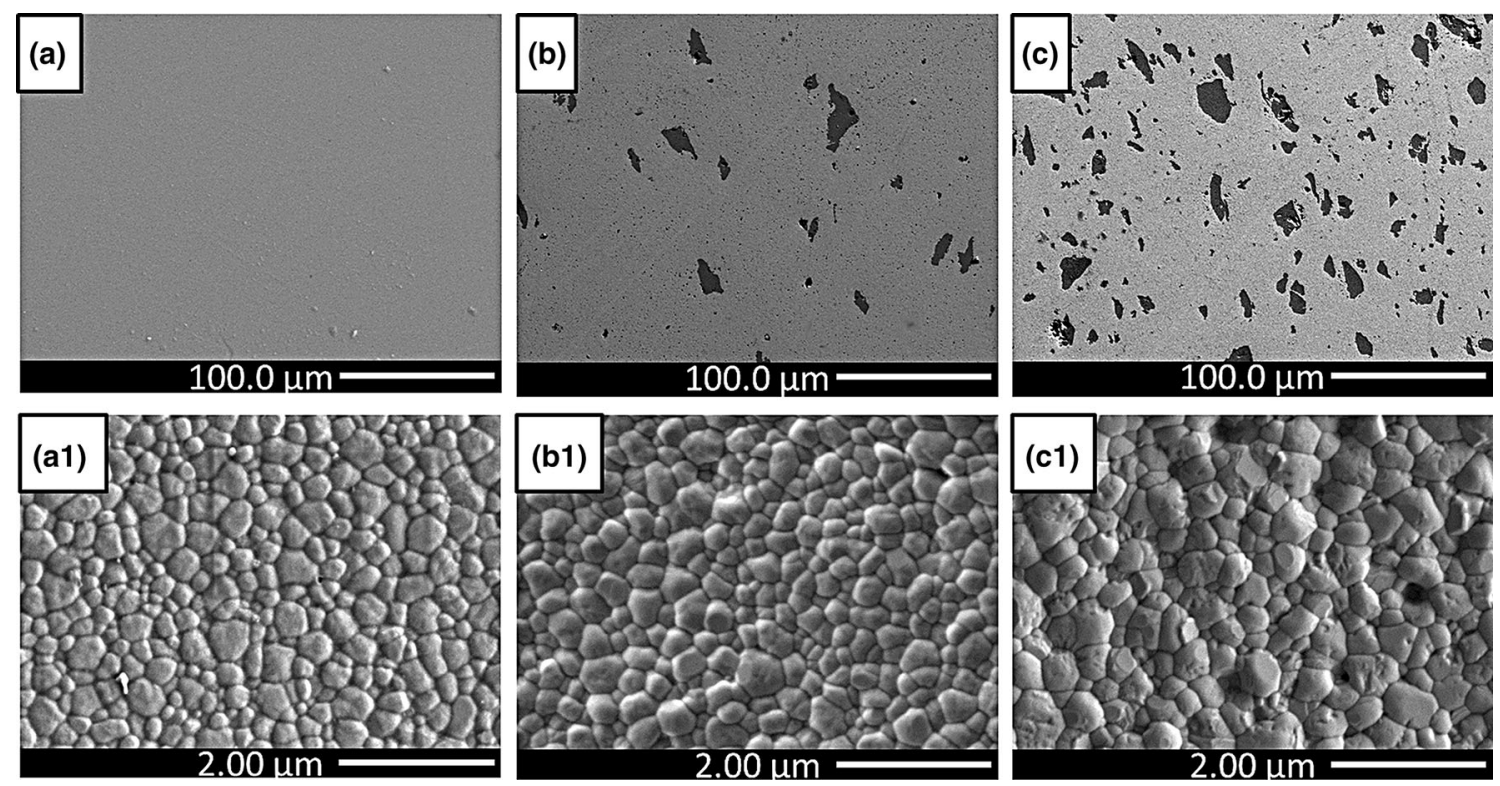

Fig. 3 Microstructure of the $3 \mathrm{Y}-\mathrm{ZrO}_{2}$ and $3 \mathrm{Y}-\mathrm{ZrO}_{2}-\mathrm{Ti}$ composites (cross section): dark contrast-Ti-rich particles $(\mathbf{a}-\mathbf{c})$ and microstructure of the $3 \mathrm{Y}-\mathrm{ZrO}_{2}$ and $3 \mathrm{Y}-\mathrm{ZrO}_{2}-\mathrm{Ti}$ composites (cross section) after

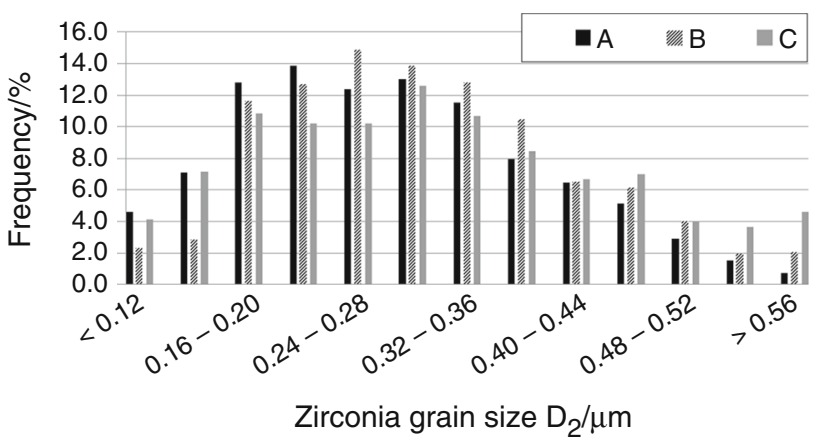

Fig. 4 Analysis of the zirconia grain size distribution-for $3 \mathrm{Y}-\mathrm{ZrO}_{2}$ sample (a) and the zirconia matrix in the $3 \mathrm{Y}-\mathrm{ZrO}_{2}-\mathrm{Ti}$ composites samples $(\mathbf{b}, \mathbf{c})$

Table 3 Equivalent average diameter of zirconia and zirconia matrix grains

\begin{tabular}{lll}
\hline & Sample & $\begin{array}{l}\text { Equivalent average } \\
\text { diameter } d_{2} / \mu \mathrm{m}( \pm \mathrm{SD})\end{array}$ \\
\hline $\mathrm{A}$ & $3 \mathrm{Y}-\mathrm{ZrO}_{2}$ & $0.28 \pm 0.11$ \\
$\mathrm{~B}$ & $3 \mathrm{Y}-\mathrm{ZrO}_{2}+3$ vol\% Ti & $0.32 \pm 0.11$ \\
$\mathrm{C}$ & $3 \mathrm{Y}-\mathrm{ZrO}_{2}+10$ vol\% Ti & $0.33 \pm 0.11$ \\
\hline
\end{tabular}

about $1300{ }^{\circ} \mathrm{C}$, the pure zirconia thermal expansion coefficient was decreased, which is related to the $\mathrm{m} \rightarrow \mathrm{t}$ transformation and the linear dimension changes (curve I) [28]. Course of the second (II) curve was different at thermal heating: $3 \mathrm{Y}-\mathrm{ZrO}_{2}$ (a1) and $3 \mathrm{Y}-\mathrm{ZrO}_{2}$ matrix in the composites (b1 and c1, respectively), SEM

temperatures higher than $1300{ }^{\circ} \mathrm{C}$. The thermal expansion coefficient slightly increased. At the same temperature, the thermal expansion coefficient of the composite with 3 vol\% Ti was increased which was associated with the small addition of $\mathrm{Ti}$ and the transition temperature conversion of $\mathrm{m} \rightarrow \mathrm{t}$ transformation (curve I) [29, 30]. The slightly lower increase was observed for the second curve (II).

In the samples with upper Ti additive (10 vol\%) in the composite samples, the significant differences were observed. At the temperature range of $50-1200{ }^{\circ} \mathrm{C}$, the thermal expansion curve (I) was closed to linear with two characteristic points at $650{ }^{\circ} \mathrm{C}$ and $1000{ }^{\circ} \mathrm{C}$. At $650{ }^{\circ} \mathrm{C}$, the small decrease in the thermal expansion coefficient was observed (about $-2.5 \times 10^{-6} \mathrm{~K}^{-1}$ ). This range of temperature could correspond with the titanium oxides transformation [26, 27]. At the second temperature point (below $1000{ }^{\circ} \mathrm{C}$ ), the thermal expansion coefficient was higher, about $10 \times 10^{-6} \mathrm{~K}^{-1}$. This point could associate with high addition of $\mathrm{Ti}(10 \mathrm{vol} \%)$ which reveal in the $\alpha \mathrm{Ti} \rightarrow \beta \mathrm{Ti}$ transformation [26]. Likewise, the curve at the temperature above $1200{ }^{\circ} \mathrm{C}$ had different characteristics. At the temperature range of $1200{ }^{\circ} \mathrm{C}$ and $1400{ }^{\circ} \mathrm{C}$, the rapid growth of thermal expansion was detected because of the $\mathrm{m} \rightarrow \mathrm{t}$ zirconia transformation. In the range of temperature $1300-1450{ }^{\circ} \mathrm{C}$, the same rapid decrease of thermal expansion was observed in all samples. The second thermal expansion curve (II) was more stable in the whole range of temperature without one characteristic point about $400{ }^{\circ} \mathrm{C}$ 

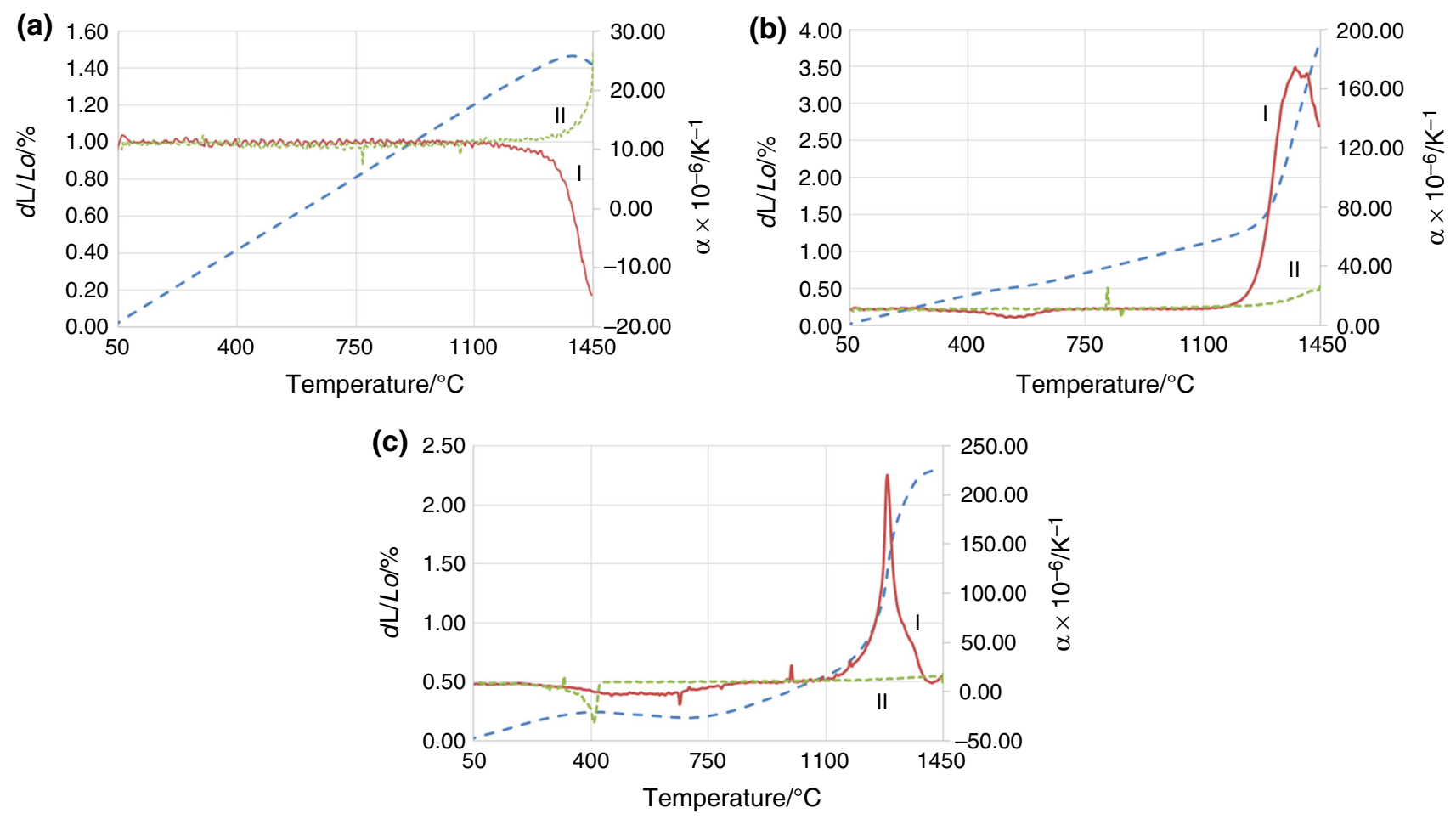

Fig. 5 Thermal expansion curves of $3 \mathrm{Y}-\mathrm{ZrO}_{2}(\mathbf{a})$ and $3 \mathrm{Y}-\mathrm{ZrO}_{2}-\mathrm{Ti}(\mathbf{b}, \mathbf{c})$ composites $(\alpha$ thermal expansion line: curve I-solid and curve IIdotted) on heating and shrinkage versus temperature (intermittent line- $\mathrm{d} L / L o$ )

which was corresponded with the beginning of the titanium oxidation.

\section{Conclusions}

Addition of Ti into $\mathrm{ZrO}_{2}$ strongly influenced the sintering behavior and thermal expansion of composites.

The thermal expansion curves were different for the pure zirconia and $3 \mathrm{Y}-\mathrm{ZrO}_{2}-\mathrm{Ti}$ composites. The changes were the result of the existing $\alpha \mathrm{Ti} \rightarrow \beta \mathrm{Ti}$ transformation and the transition temperature conversion of zirconia $\mathrm{m} \rightarrow \mathrm{t}$ transformation.

The data obtained from the mass spectrometer coupled with the thermobalance reveal that the predominant gaseous products released from the samples during thermal treatment are $\mathrm{H}_{2} \mathrm{O}, \mathrm{CO}_{2}$, and $\mathrm{CO}$ in the case of the measurements carried out in $\mathrm{Ar}$ atmosphere. At $838.6^{\circ} \mathrm{C}$, probably the exothermic reaction of $\alpha \mathrm{Ti} \rightarrow \beta \mathrm{Ti}$ was observed.

Selected temperature of fabrication of $\mathrm{ZrO}_{2}-\mathrm{Ti}$ composites was $1450{ }^{\circ} \mathrm{C}$. The analysis of the sintering process and characteristic temperatures confirmed the influence of the $\mathrm{Ti}$ addition on the onset and final temperature of shrinkage which increased with the increase of Ti content. The maximum shrinkage temperatures were about $1300{ }^{\circ} \mathrm{C}$.
Using the slip casting method allowed producing the zirconia and composite samples with the relative density about $98 \%$, close to theoretical density. The addition of titanium did not significantly decrease the material hardness. The microstructure observations showed the homogeneous distribution of the Ti-rich phase areas in the composite samples. The zirconia grain size slightly increased with the increase of $\mathrm{Ti}$ content.

Determining sintering conditions and its effect on the properties of zirconia-titanium composites are the basis for further analyses. The next step of investigation should be the phase analysis of composites and description the microstructure on the particle-matrix interface.

Acknowledgements The work was done in frame of the project financed by National Science Centre (NCN), Project DEC-2013/11/B/ ST8/00309.

Open Access This article is distributed under the terms of the Creative Commons Attribution 4.0 International License (http://crea tivecommons.org/licenses/by/4.0/), which permits unrestricted use, distribution, and reproduction in any medium, provided you give appropriate credit to the original author(s) and the source, provide a link to the Creative Commons license, and indicate if changes were made. 


\section{References}

1. Bowen P, Carry C. From powder to sintered pieces: formation, transformation and sintering of nanostructured ceramic oxides. Powder Technol. 2002;128:248-55.

2. Miller RA. Current status of thermal barrier coatings: an overview. Surf Coat Technol. 1987;30:1-11.

3. Chevalier J, Gremillard L, Virkar AV, Clarke DL. The tetragonal-monoclinic transformation in zirconia: lesson learned and future trends. J Am Ceram Soc. 2009;92(9):1901-20.

4. Zender $\mathrm{H}$, Leistner $\mathrm{H}$, Searle $\mathrm{H}$. $\mathrm{ZrO}_{2}$ materials for applications in the ceramic industry. Int Ceram. 1990;39(6):33-6.

5. Vogt T, Hunter BA, Thornton J. Structural evolution of thermalsprayed yttria-stabilized $\mathrm{ZrO}_{2}$ thermal barrier coatings with annealing: a neutron diffraction study. J Am Ceram Soc. 2001;84(3):678-80.

6. Kosmac T, Oblak C, Marion L. The effects of dental grinding and sandblasting on ageing and fatigue behaviour of dental zirconia (Y-TZP) ceramic. J Eur Ceram Sci. 2008;28:1085-90.

7. Wildan M, Edrees HJ, Alan H. Ceramic matrix composites of zirconia reinforces with metal particles. Mater Chem Phys. 2002;75(1-3):276-83.

8. Bartolome JF, Gutierrez-Gonzalez CF, Pecharroman C, Moya JS. Synergistic toughening mechanism in $3 \mathrm{Y}-\mathrm{TZP} / \mathrm{Nb}$ composites. Acta Mater. 2007;55:5924-33.

9. Niinomi M. Mechanical properties of biomedical titanium alloys. Mater Sci Eng. 1998;A243:231-6.

10. Boyer R, Collings EW, Welsch G. Materials properties handbook: titanium alloys. ASM Int. 1994;1-55.

11. Mehrali M, Shirazi FS, Mehrali M, Metselaar HSC, Kadri NAB, Osman NAA. Dental implants from functionally graded materials. J Biomed Mater Res A. 2013;101(10):3046-57.

12. Gain AK, Zhang L, Quadir MZ. Composites matching the properties of human cortical bones: the design of porous titanium zirconia $\left(\mathrm{Ti}-\mathrm{ZrO}_{2}\right)$ nanocomposites using polymethyl methacrylate powders. Mater Sci Eng A. 2016;662:258-67.

13. Kaliaraj GS, Kirubaharan K, Pradhaban G, Kuppusami P, Vishwakarma V. Isolation and characterization of biogenic calcium carbonate/phosphate from oral bacteria and their adhesion studies on YSZ-coated titanium substrate for dental implant application. Bull Mater Sci. 2016;39(2):385-9.

14. Weber BC, Garrett HJ, Mauer FA, Schwartz MA. Observation on the stabilization of zirconia. J Am Ceram Soc. 1956;39(6):197-206.

15. Ruh R, Tallan NM, Lipsitt HA. Effect of metal additions on the microstructure of zirconia. J Am Ceram Soc. 1964;47(12):632-5.
16. Lin KL, Lin CC. Zirconia-related phases in the zirconia/titanium diffusion couple after annealing at $1100-1550^{\circ} \mathrm{C}$. J Am Ceram Soc. $2005 ; 88(10): 2928-34$.

17. Lin KL, Lin CC. Effects of annealing temperature on microstructural development at interface between zirconia and titanium. J Am Ceram Soc. 2007;90(3):893-9.

18. Lin $\mathrm{KL}$, Lin $\mathrm{CC}$. $\mathrm{Ti}_{2} \mathrm{ZrO}$ phases formed in the titanium and zirconia interface after reaction at $1550^{\circ} \mathrm{C}$. J Am Ceram Soc. 2005;88(5):1268-72.

19. Matsui K, Yoshida H, Ikuhara Y. Grain-boundary structure and microstructure development mechanism in 2-8 mol\% yttria-stabilized zirconia polycrystals. Acta Mater. 2008;56:1315-25.

20. Munoz-Tabares JA, Jimenez-Pique E, Reyes-Gasga J, Anglada M. Microstructural changes in ground 3Y-TZP and their effect on mechanical properties. Acta Mater. 2011;59:6670-83.

21. Ding LX, Wang L, Nagashima M, Hayakawa M. A dilatometric study of the martensitic transformation of zirconia containing 1.8-2.0 mol\% yttria. Mater Trans. 2001;42(3):450-2.

22. Surzhikov AP, Ghyngazov SA, Frangulyan TS, Vasil'ev IP, Chernyavskii AV. Investigation of sintering behaviour of $\mathrm{ZrO}_{2}$ (Y) ceramic green body by means of non-isothermal dilatometry and thermokinetic analysis. $\mathrm{J}$ Therm Anal Calorim. 2017;128(2):787-94.

23. Lopez-Lopez E, Baudin C, Moreno R. Thermal expansion of zirconia-zirconium titanate materials obtained by slip casting of mixtures of Y-TZP-TiO 2 . J Eur Ceram Soc. 2009;29:3219-25.

24. Lada P, Falkowski P, Miazga A, Konopka K, Szafran M. Fabrication of $\mathrm{ZrO}_{2}-\mathrm{Ti}$ composites by slip casting method. Arch Metall Mater. 2016;61(2B):1095-100.

25. Wejrzanowski T, Pielaszek R, Opalinska A, Matysiak $\mathrm{H}$, Łojkowski W, Kurzydłowski KJ. Quantitative methods for nanopowders characterization. Appl Surf Sci. 2006;253:204-8.

26. Wahlbeck PC, Gilles PW. Reinvestigation of the phase diagram for the system titanium-oxygen. $\mathrm{J}$ Am Ceram Soc. 1966;49(4):180-3.

27. Teng LD, Wang FM, Li WC. Thermodynamics and microstructure of $\mathrm{Ti}-\mathrm{ZrO}_{2}$ metal-ceramic functionally graded materials. Mater Sci Eng. 2000;A293:130-6.

28. Basu B, Vleugels J, Van Der Biest O. Transformation behaviour of tetragonal zirconia: role of dopant content and distribution. Mater Sci Eng A. 2004;366(2):338-47.

29. Domagala RF, Lyon SR, Ruh R. The pseudobinary Ti- $\mathrm{ZrO}_{2}$. J Am Ceram Soc. 1973;56(11):584-7.

30. Teng LD, Li WC, Wang FM. Effect of Ti content on the martensitic transformation in zirconia for $\mathrm{Ti}-\mathrm{ZrO}_{2}$ composites. J Allloys Compd. 2001;319:228-32. 